\title{
大腿骨転子部骨折に対する骨接合術の治療成績
}

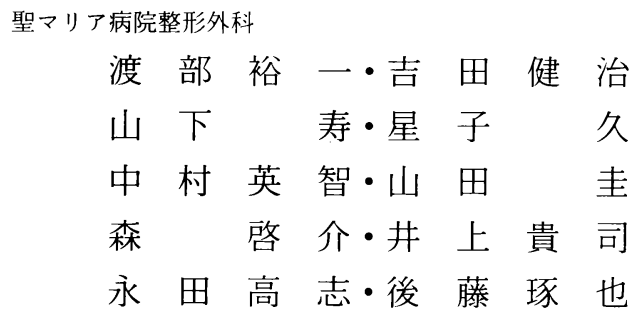

\section{Treatment of Peritrochanteric Fractures Using Gamma Nail}

\author{
Yuichi Watanabe, Kenji Yoshida, Hisashi Yamashita, Hisashi Hoshiko, \\ Hidetomo Nakamura, Kei Yamada, Keisuke Mori, Takashi Inoue, \\ Takashi Nagata, and Takuya Gotoh \\ Department of Orthopaedic Surgery, St. Mary's Hospital, Kurume, Fukuoka, Japan
}

\begin{abstract}
We reviewed the early clinical results of 117 peritrochanteric fractures treated with the Gamma nail. The average age of the patients was 77 years. The mean follow-up period was 264 days. The fractures were grouped into 5 types according to Jensen's classification. There was a significant difference in the sliding of lag screws between stable and unstable fractures. The main post-operative complication was cut out of the lag screw. It is essential to decide their operative indications carefully, because peritrochanteric fractures with fractures at the base of the femoral neck showed poor results.
\end{abstract}

Key words : Gamma nail（ガンマーネイル), cut out（カットアウト), peritrochanteric fracture（転 子部骨折）

は じめに

近年，大腿骨転子部骨折に対する Gamma nail に よる骨接合術の術後成績は安定した成績が報告されて

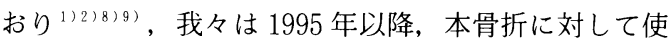
用している．今回その臨床評価，レントゲン評価，合 併症について報告する。

\section{対象及び方法}

対象は 1995 年 5 月から 2000 年 12 月までの期間に おいて大腿骨転子部骨折患者 117 例，その内訳は男性 29 例, 女性 88 例, 受傷時平均年齢は 77 歳, 平均観
察期間は 264 日だった。

骨折型は Jensen 分類 ${ }^{4)}$ にて分類し, タイプ 115 例, タイプ 225 例, タイプ 329 例, タイプ 4 25 例, タイプ 523 例で, タイプ1及び 2 を stable type, タイプ $3,4,5$ を unstable type とした. 検 討項目は, 手術時間, 術中出血量, 歩行能力の变化, 荷重開始時期, 在院日数, 術中術後合併症について評 価し, 歩行能力については, $\mathrm{N}$ 式老年者用日常生活能 力評価尺度 ${ }^{6)}$ を用いて点数化して評価した.

X線評価については Kawaguchi らの方法を用い て ${ }^{5)}$, レントゲン正面, 側面像に抢ける骨片間離開度, ラグスクリューの深達度, ラグスクリューの傾斜度に 

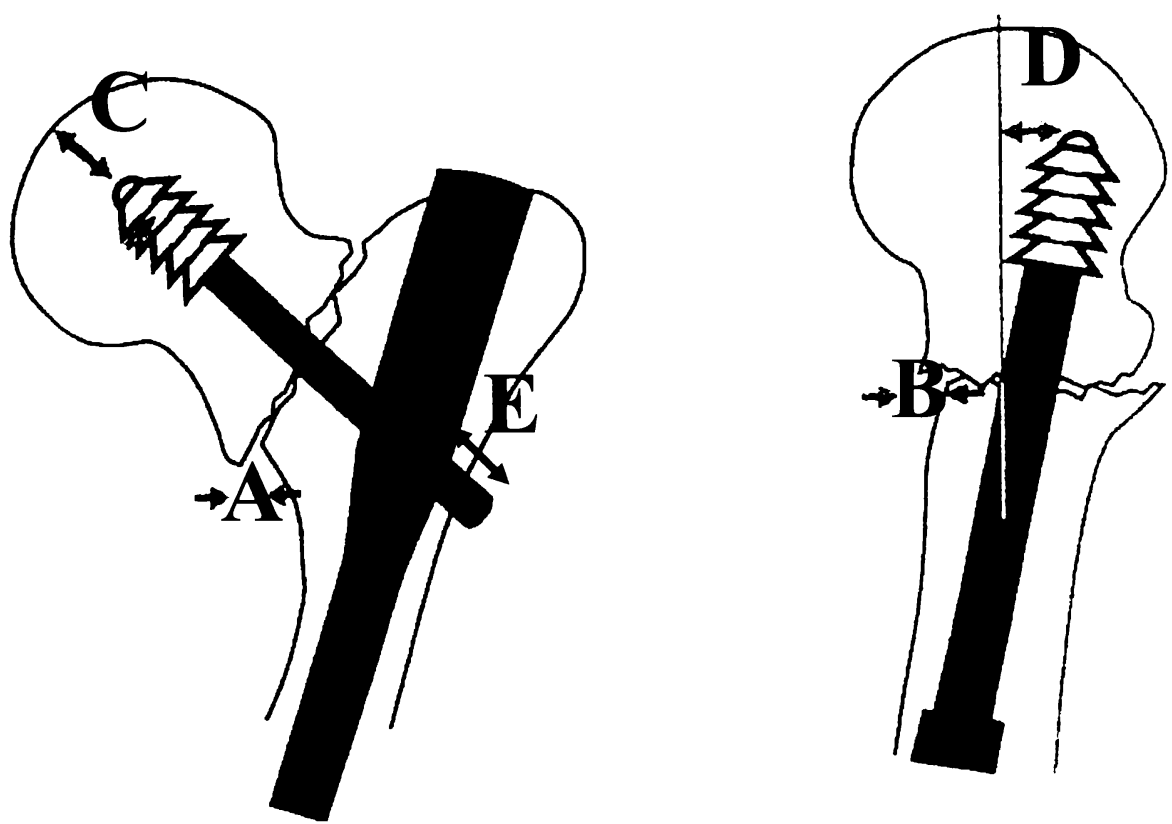

\section{A: Diastasis on anteroposerior radiograph B: Diastasis on lateral radiograph C: Depth of screw D: Lateral deviation of screw E: The length of sliding of the lag screw}

図 1 X線評価

ついて計測し, cut out 発生率との関係についてカイ 二乗検定を用いて評価した（図 1 ）.

尚, 当院では, 手術において nail の挿入に際して リーミングは原則として小転子レベルまでとし, distal locking screw は初期では2 本固定していたが, 同部での骨折例を経験してから, 最近では 1 本のみと している. また, 後療法は術後翌日より原則として荷 重歩行を開始している.

\section{結果}

術中平均出血量は 121 グラム, 平均手術時間は 55 分, 手術待機期間は平均 11 日, 荷重開始時期は平均 8 日, 平均在院日数は 59 日だった。歩行能力は低下 傾向であり, 受傷前正常であった 61 例のうち, 術後

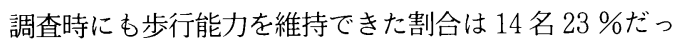

た.ラグスクリューのスライディング量は安定型では 中央值 $4.5 \mathrm{~mm}$, 不安定型では中央值 $6 \mathrm{~mm}$ と統計学 的に有意差を認め，不安定型に有意に大きく認めた (図 2 ).

骨片間の離開度はレントゲン正面像にて $5 \mathrm{~mm}$ 末 満で cut out 発生率は $3 \%$ ，5 mm 以上で $17 \%$ 之統 計学的に有意差を認め, 側面像では cut out の発生率 に統計学的に有意差を認めなかった（図 3 ). Lag screw の深達度, 傾斜度において, cut outの発生率 は $9 \mathrm{~mm}$ 以下の群と $10 \mathrm{~mm}$ 以上の群に, 統計学的に 有意差を認めなかった。術中術後合併症は cut out 8 例と最む多く認めた（図 4 ).

症例

症例 $1 ： 87$ 歳, 女性, 受傷時レントゲンは Jensen 


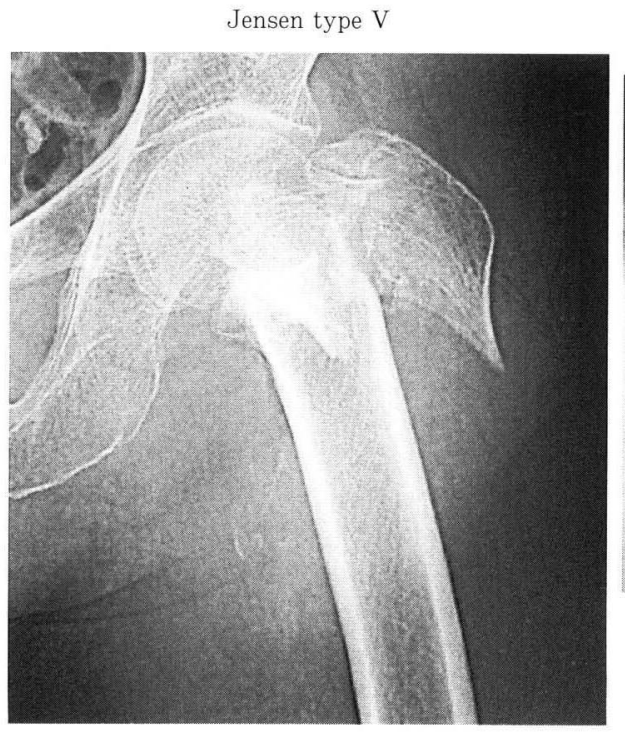

$87 \mathrm{~F}$

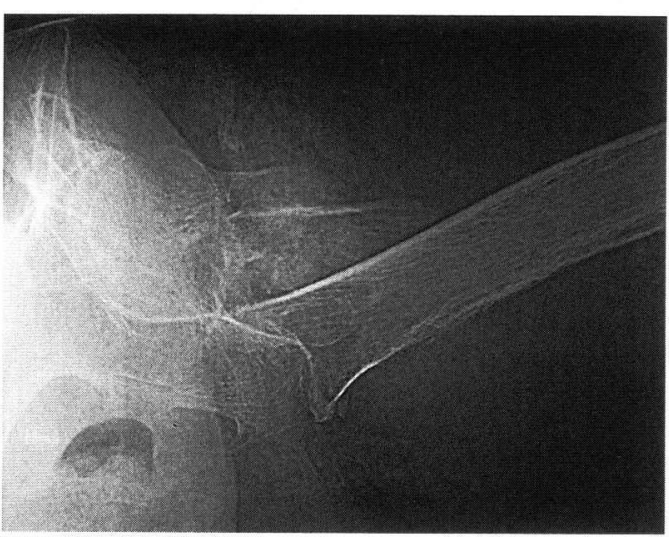

On set
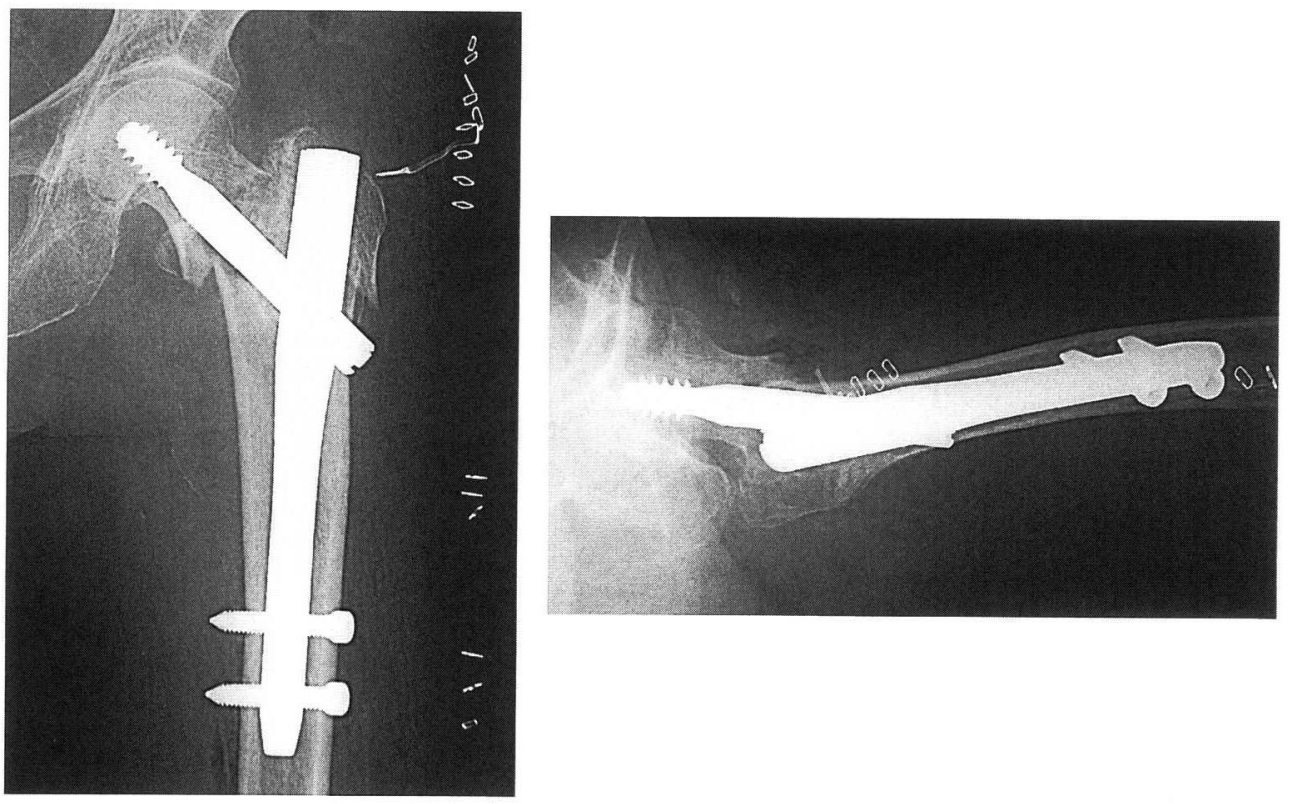

Post op. 

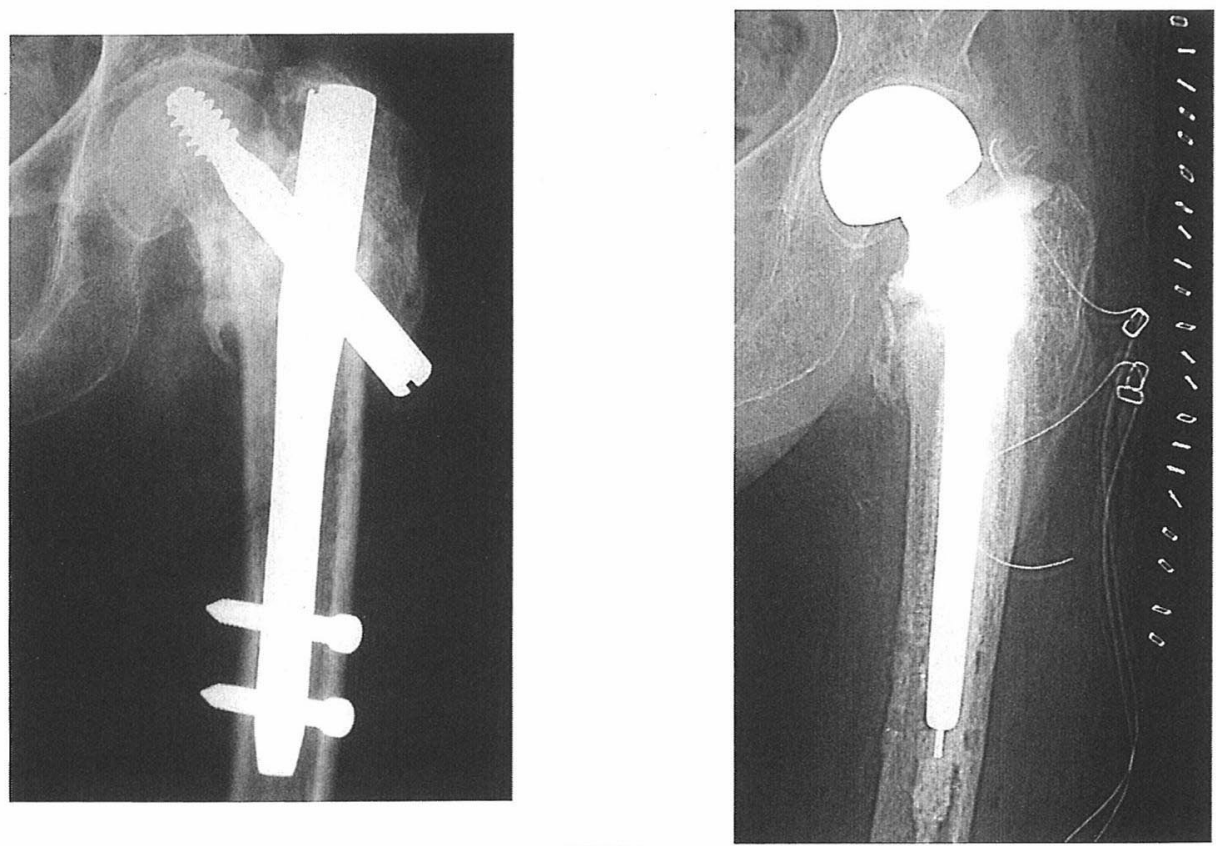

PO 3M.

症例 1

Jensen type III

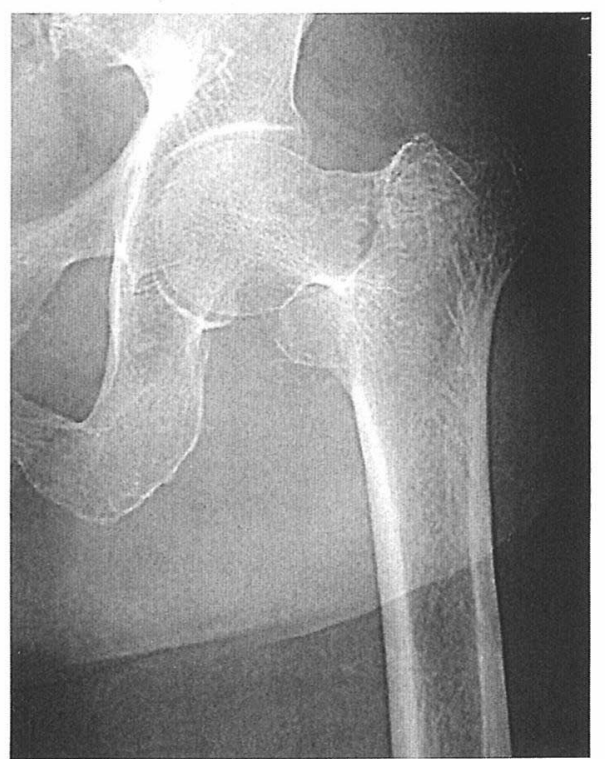

$82 \mathrm{~F}$

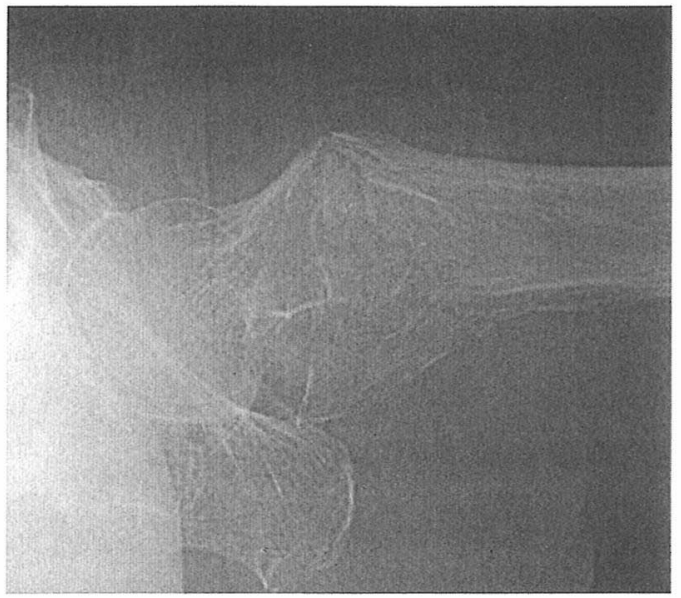

On set 

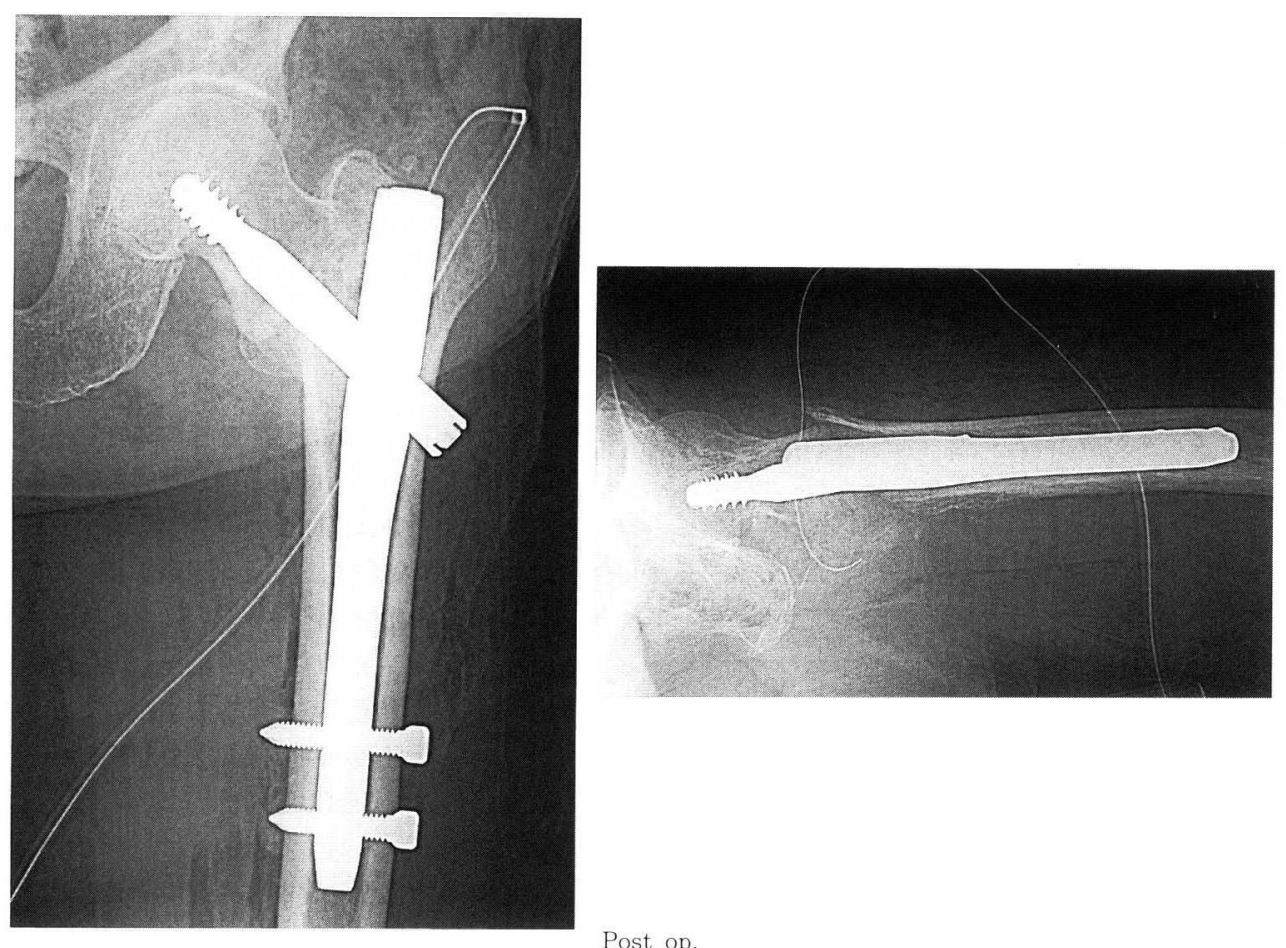

Post op.
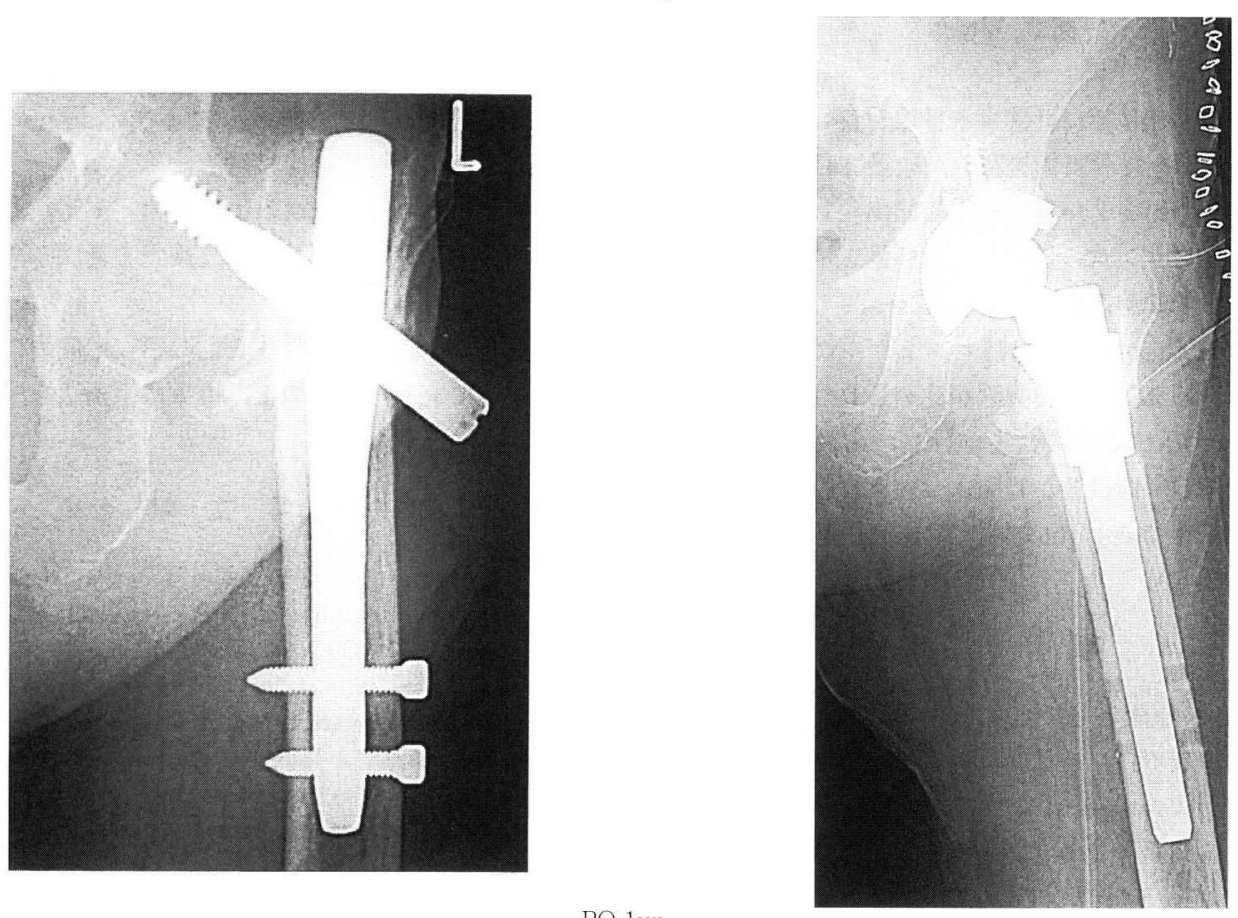

PO 1yr.

症例 2 


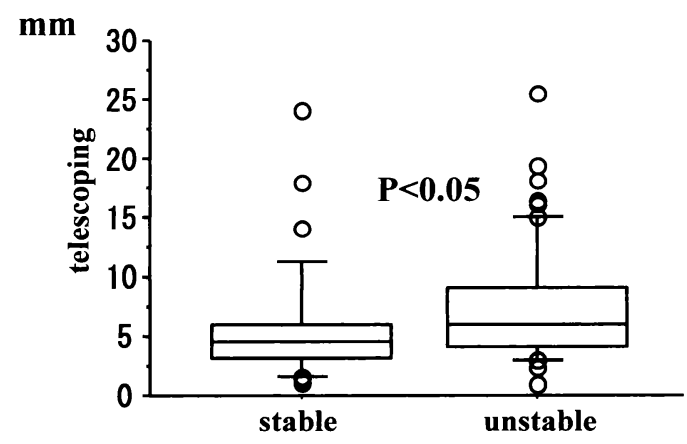

図 2 lag screw $の$ sliding 量

\begin{tabular}{|c|c|c|c|}
\hline & \multicolumn{3}{|c|}{ 偽関節率 } \\
\hline & Number & & $\%$ \\
\hline \multicolumn{4}{|c|}{ 骨片間の離開（AP） } \\
\hline$<5 \mathrm{~mm}$ & $3 / 88$ & 3 & $\mathrm{P}<000$ \\
\hline$\geqq 5 \mathrm{~mm}$ & $5 / 29$ & $17)$ & $\mathrm{P}<0.05$ \\
\hline \multicolumn{4}{|c|}{ 骨片間の離開（Lateral） } \\
\hline$<5 \mathrm{~mm}$ & $6 / 96$ & 6 & $\mathrm{NS}$ \\
\hline$\geqq 5 \mathrm{~mm}$ & $2 / 21$ & 9 & N.S \\
\hline
\end{tabular}

図 3 整復度

5，大腿骨頝部基部に近接する骨片を有していた。

受傷後 5 日目で骨折術施行し, 術後 3 日上り歩行訓 練開始したが術後 2 か月で股関節痛出現し，レントゲ ン上ラグスクリューの骨頭内上方移動を認め, 術後 3 か月で人工骨頭置換術となった（図 5 ).

症例 $2 ： 82$ 歳女性, 受傷時レントゲンで Jansen 3 で，大腿骨頚部基部に骨折線が認められた。

受傷後, 12 日で骨接合術施行し, 術後翌日より歩 行訓練開始し, 術後 3 か月頃より徐々に股関節痛出現 し, 術後 1 年で cut out 判明し, 人工股関節置換術施 行した（図6).

\section{考察}

cut out の原因として，井上ら ${ }^{3)}$ はラグスクリュー の骨頭内位置不良，ラグスクリューの不十分な挿入深 度をあげ，Kawaguchi らゔはラグスクリューの浅い 挿入深度, 側面像でのラグスクリューの著明な傾斜度 が原因である之報告している，当院のデータでも， cut out した 8 例のうち，ラグスクリュ一の骨頭内位 置不良が原因と思われる症例が 3 例ほよ゙あり十分に注

\begin{tabular}{cr}
\hline \hline Cut out & 8 例 \\
内反変形 & 5 例 \\
二次性大腿骨骨幹部骨折 & 2 例 \\
Infection & 4 例 \\
Bursa 形成 & 1 例 \\
$15 \mathrm{~mm}$ 以上の Back out & 11 例 \\
\hline
\end{tabular}

図 4 術中術後合併症

意を払う必要がある。また, 今回, cut out の発生率 に関してレントゲン正面像での骨片間の離開度に有意 差を認めたが, cut out の発生を軽減するためにも, 可能な限り良好な整復位を獲得する必要があると思わ れた. 当院での症例で, 大腿骨䫋部基部に骨折線が見 られる不安定型症例 7 例のうち cut out 3 例, 内反变 形 1 例を認めた。正田ら" は Gamma nail の適応外 症例として大腿骨頚部基部骨折を挙げ，このような症 例に使用すると骨頭が回転して十分な固定性が得られ ず cut out を生じる危険性があると述べている. 今後, このような骨折型に対する固定法については，骨折型 を充分精查した上で, 慎重に決定する必要があると思 われた。

結語

大腿骨転子部骨折 117 例に対して Gamma nail を 施行し，その術後成績を検討した。

術後合併症として cut out 8 例 ( $7 \%$ ) と最屯多 く認め, 内 3 例が頚部基部に近接する骨片を含む不安 定型症例であった。

頝部基部に近接する骨片を含む不安定症例は骨折型 にたいして充分な精查の上，慎重に手術法を決定する 必要があると思われた。

\section{参 考 文 献}

1) Groose A : A new device for the treatment of trochanteic fractures : The intramedually Gamma locking nail. 1990 AAOS Proceedings.

2) Halder S. C. et al : The Gamma nail for peritrochanteric fractures. J Bone Joint Surg 74-B : 340-344, 1992.

3）井上尚美ほか：Gamma AP nailing の術後合併症 $-\mathrm{X}$ 線計測と cutting out. 骨折 $17: 470-475,1995$.

4) Jensen J. S. et al : Classification of trochanteric fractures. Acta Orthop Scand 51:803-810, 1980.

5) Kawaguchi $\mathrm{S}$ et al : Cutting out of the lag screw after internal fixation with the Asiatic gamma nail. 
Injury $29: 47-53,1998$.

6）西村健ほか：脳の老化. 理学療法 $6: 381-387,1989$

7）正田悦朗ほか：ガンマネイルの応用と合併症．整・災 外41: 957-966, 1998.

8）吉田健治ほか：大腿骨転子部骨折に対する Gamma
Locking Nail 法と DHS 法の比較. 骨折 17: 489-494, 1995.

9）吉田健治ほか：大腿骨転子部骨折に対する Gamma nail の治療成績. 骨折 $19: 103-108,1997$. 